\title{
Improvement of Fuel properties and Fatty Acid Composition of Biodiesel from Waste Cooking Oil after Refining Processes
}

\author{
Aliru O. Mustapha, Rasidat A. Adepoju, Rofiat Y. Ajiboye, Yemisi T. Afolabi, Samsudeen O Azeez and Abdulfatai T \\ Ajiboye \\ Department of Chemical, Geological \& Physical Sciences, College of Pure and Applied Sciences, Kwara State University Malete, \\ PMB 1530, Ilorin, Kwara State, Nigeria \\ DOI: https://dx.doi.org/10.51244/IJRSI.2021.8405
}

\begin{abstract}
This work compares the physicochemical properties and fatty acid (FA) compositions of waste cooking oil (WCO) collected after deep frying periods from local restaurant with samples of refined cooking oil (RCO) produced after degumming, alkaline and bleaching treatments. The refined oil were initially kept/stored in the refrigerator at $4^{\circ} \mathrm{C}$ and the biodiesel produced was subjected to gas chromatography mass spectroscopy (GCMS) for FA profile, and to Fourier Transform Infrared (FTIR) analyses to monitor esterification reactions. The degree of oil usage affected WCO properties and fatty acid composition. Density of refined cooking oil RCO and WCO varied between 0.90 and $0.93\left(\mathrm{~g} / \mathrm{cm}^{3}\right)$, and of refined cooking methyl ester (RCME) and waste cooking methyl ester (WCME) between 0.88 and $0.91\left(\mathrm{~g} / \mathrm{cm}^{3}\right)$. The $\mathrm{pH}$ of $\mathrm{RCO}$ and $\mathrm{WCO}$ varied between 7.36 and 8.61 and that of RCME and WCME between 5.11 and 5.59. The results of RCO and RCME showed corresponding improvements over the WCO and WCME in recovery yield, acid value, saponification value, iodine value, peroxide value, cetane number, kinematic viscosity, pour, smoke, flash, and fire points. Fatty acids analyses similarly showed comparable differences between the RCO and WCO with percent increase in octanoic ethyl acid $(276.54 \%)$, benzoic acid, butyl ester (69.79\%), hexadecanoic acid 15- methyl esters $(267.33 \%)$ and reduction in $9,17-$ Octadecanoic acid $(99.20 \%)$, and 9- octadecenoic acid(35.98\%), respectively. The hexadecanoic acid, methyl ester $(54.10 \%)$ was the most abundant. This result confirms the suitableness of WCO as feedstock for biodiesel.
\end{abstract}

Keywords: biodiesel, waste cooking oil, refined oil, fatty acids, physicochemical.

\section{INTRODUCTION}

$\mathrm{T}$ he energy demand is ceaselessly increasing because of quick industrial enterprise and cosmopolitan growth [1 3]. The key to energy resources are crude oil, coal and fossil fuel and due the non-renewable nature, these energy sources are decreasing day by day [4]. Each energy and environmental deterioration are serious crisis, that may probably be reduced by adopting energy sources for biofuels like biodiesel generation in addition to the adoption of environmental friendly ways for its generation [5]

In distinction to traditional crude oil diesel, the biodiesel may be a clean, safe and non-hazardous because of its biodegradability, renewable and carbon neutral nature. Chemically, biodiesel is fatty acid methyl group esters (FAME), which might be synthesized by chemical change between alcohol and oil in presence of an appropriate catalyst, and feedstocks like energy cops, animal fats, room wastes, insects and microalgae are often used for the assembly of biodiesel [6]. From 2008 to 2018, world ethanol and biodiesel production (in million tonnes oil equivalent) with Europe and USA as main producers but the key obstacle within the exploitation of biodiesel is the price of production arising from using edible vegetable oils have been allayed by studies on the use of non-edible vegetable and WCOs [7].

In this regard, the exploitation of waste materials for the assembly of biodiesel can be helpful to scale back the feedstock price that makes the method economical. The spent oil may be a waste, which might be regenerated into biodiesel and this may be useful for the reduction of pollution since waste vegetable oil (WCO) is wasted into the environment. Secondly, the conversion of WCO into biodiesel may be a valuable addition of energy in existing energy grid [8]. Some edible vegetable oils like corn, canola, soybean, are used in biodiesel production and are verified diesel replacements [4, 5]. One approach to scale back the price of this fuel is to use the most cost-effective feedstocks as well as non-edible oil, spent/waste cooking oils and refined vegetable oils that involve low harvest prices. The $\mathrm{WCO}$ will be processed to sophisticated oil (RCO) to manufacture waste cooking methyl ester (WCME) and refined cooking methyl ester (RCME). The refined biodiesel from WCO; was way more costeffective than eatable oil as it was preferable to relatively expensive edible oils [9]. Spent cooking oil and fats set forth substantial discarding problems in many parts of the world and this environmental nasty drawback can be turned into an economic and eco-friendly advantage by applicable utilization and managing of waste vegetable oil as a fuel feedstock. Biodiesel is normally made via transesterification reaction process from fats and oils either bio-chemically or with chemicals in the literature; the best used method because it decreases the viscosity of the biodiesel [10 - 17]. The research therefore focused on the biodiesel synthesis using low-cost 
feedstocks such as WCOs to determine and compare the quality of the biodiesels produced from it and RCOs with the American Society for Test and Material (ASTM) standards $[14,18]$.

\section{MATERIALS AND METHODS}

\subsection{Materials and Chemicals}

Chemicals and apparatus were obtained from Sigma Aldrich (Gillingham Dorset, UK), LGC (Teddington Middlesex, UK), and Cerrilliant (Round Rock, TX, USA). Biodiesel analyses were carried out using reflux set, micro-pipette, thermostated water-bath, digital hot plate/magnetic stirrer, separating funnel, pycnometer (ASTM D941), bomb calorimeter (Parr1351 from Parr Instrument Company, Moline, IL, USA), Cannon-Fenske viscometer ostwald (Cannon Instrument Co., State College, PA, USA) etc, and pH meter (Hanna HI 4212 model).

Waste cooking oil (WCO) of sunflower from a food restaurant in Ilorin, Kwara State, Nigeria was produced after deep frying of foods and was used as feed stock of biodiesel production.

\subsection{Oil Purification}

2.2.1 Refining processes of WCO: Refinement of the crude oil (waste cooking oil) is removing impurities using degumming, alkaline and bleaching treatments prior to efficient trans-esterification as earlier described in the literature [8]

2.2.2 Pretreatment of $R C O$ : The acid esterification required the free fatty acid (FFA) value to be brought below $0.5 \%$, and for process to proceed to transesterification

2.2.3 Trans-esterification process of WCO and RCO to methyl esters: The Trans-esterification process involved the heating of mixture of oils and methanol in molar ratio using American Society for Test and Material (ASTM) standards [14, 18]

\subsection{Physicochemical properties and analysis}

Physical properties of oils and biodiesels were carried out using American Society for Test and Material (ASTM) Quality Evaluations [14, 18].

\subsection{Determination of fuel properties}

The higher heating value, kinematic viscosity, cetane number, pour, flash, cloud, smoke points, and specific gravity by ASTM $[14,18]$.

2.5 Determination of free fatty acid profile of WCME and RCME: GC-MS analysis was carried out using Varian 3800 gas -chromatography coupled with Agilent MS capillary column (30 $\mathrm{m} \times 0.25 \mathrm{~mm}$ i.d) [8].

2.6 FTIR measurement of WCME and RCME: FTIR analysis was carried out using Shimadzu equipment. KBr (Potassium bromide, spectroscopy grade) was grounded into (powdery form) pelletized (with hydraulic press) and scanned with instrument as background. Then drops of samples were separately mixed with $\mathrm{KBr}$ and was pelletized using hydraulic press, inserted into the instrument and scanned at a frequency range of $4000-400 \mathrm{~cm}^{-1}$

\section{RESULTS AND DISCUSSION}

\subsection{Chemical properties of WCO, RCO, WCME and RCME}

Figure 1 shows the RCO after it was subjected to three different refining processes of degumming, alkaline and bleaching treatments to produce biodiesel [8].

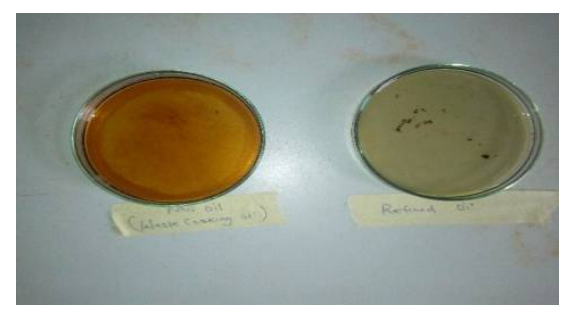

Figure 1: Waste cooking oil (WCO) - on the left and refined cooking oil $(\mathrm{RCO})$ - on the right

The quality of biodiesel is strongly dependent on a number of factors namely: quality of the feedstock, free fatty acid composition of the stock feed, handling, storage of the feed stock (WCO) and manufacturing process during production.

Table 1 presents the chemical and fuel parameters obtained for WCO, RCO, WCME and RCME. The acid value was drastically reduced after refinement to $0.77 \mathrm{mgNaOH} / \mathrm{g}$. The acid values of $5.89 \mathrm{mg} / \mathrm{g}$ found before refinement was very high, which may be due to larger number of free fatty acids available in the oil due to continuous hydrolytic cleavage of ester bonds during frying processes. The huge reduction of $86.92 \%$ FFA in the RCO encourages the recycling prospect of the used oils, and it has gained better domestic and industrialized use with improved resistance to oxidative damage. The acid values were: WCO (5.89 $\mathrm{mg} / \mathrm{KOH})$, WCME (2.53 mg/KOH), RCO (0.77 mg/KOH) and RCME $(0.03 \mathrm{mg} / \mathrm{KOH})$, respectively.

However, the acid value in this work was considerably lower than the $6.1721 \mathrm{mg} / \mathrm{KOH}$ from the biodiesel produced from waste cooking oil reported by Rahadanti et al [11]. The acid values ranges of $1.32-3.6 \mathrm{mg} / \mathrm{KOH}$ have also been reported for waste cooking oil in the literature (Mohammed and Bhargavi) [18-19]. Again, Omojola [20] reported the acid values of some waste cooking oils like sunflower, depot margarine, sunf oil and palm oil as 2.29, 2.87, 0.72 and 0.66 $(\mathrm{mg} / \mathrm{KOH})$ against the acid value of $5.89 \pm 0.14(\mathrm{mg} / \mathrm{KOH})$ observed in this work. However, acid value $0.03 \mathrm{mg} / \mathrm{KOH}$ reported for RCME here falls within the ASTM D6751-09 Standards $(<0.8 \mathrm{mg} / \mathrm{KOH})[18]$.

The peroxide value of $\mathrm{WCO}$ after refinement decreased from 2.60 to $1.20 \mathrm{Meq}_{2} / \mathrm{kg}$, representing about $53.8 \%$ reduction. The differences in peroxide values of 65.76 and $59.64 \mathrm{Meq}$ $\mathrm{O}_{2} / \mathrm{kg}$ were observed from refinement of Citrullus. colocynthis and Pongamia pinnata oils as reported by Duhan [21]. However, the current peroxide value falls within the 
specified standard for peroxide value by Codex (10meq $\mathrm{O}_{2} / \mathrm{kg}$ ) for vegetable oil deterioration. Also, $2.96 \pm 0.34$ (Meq
$\mathrm{O}_{2} / \mathrm{kg}$ ) reported for RCME falls within the ASTM D6751-09 Standards (10 $\mathrm{Meq} \mathrm{O}_{2} / \mathrm{kg}$ ).

Table 1: Chemical and fuel properties of waste and refined cooking oils and their methyl esters

\begin{tabular}{|c|c|c|c|c|c|}
\hline \multirow[b]{2}{*}{ Properties } & \multicolumn{2}{|l|}{ Before refinement } & \multicolumn{2}{|l|}{ After refinement } & \multirow[b]{2}{*}{$\begin{array}{l}\text { ASTM D6751-09 } \\
\text { Standards [19] }\end{array}$} \\
\hline & $\begin{array}{l}\text { Waste cooking oil } \\
\text { (WCO) }\end{array}$ & $\begin{array}{l}\text { Waste cooking } \\
\text { methyl ester } \\
\text { (WCME) }\end{array}$ & $\begin{array}{l}\text { Refined cooking oil } \\
\text { (RCO) }\end{array}$ & $\begin{array}{l}\text { Refined cooking methyl } \\
\text { ester } \\
\text { (RCME) }\end{array}$ & \\
\hline \multicolumn{6}{|l|}{ Chemical properties } \\
\hline Acid value, $(\mathrm{mg} / \mathrm{KOH})$ & $5.89 \pm 0.14$ & $2.53 \pm 0.07$ & $0.77 \pm 0.01$ & $0.03 \pm 0.02$ & $<0.8$ \\
\hline Saponification,(mg/KOH) & $197.50 \pm 2.12$ & $188.4 \pm 0.03$ & $156.21 \pm 0.02$ & $249.45 \pm 0.07$ & $<312$ \\
\hline Iodine Value, $\left(\mathrm{I}_{2} / 100 \mathrm{~g}\right)$ & $146.64 \pm 0.23$ & $88.6 \pm 0.01$ & $135.51 \pm 0.42$ & $117.99 \pm 0.67$ & $<120$ \\
\hline Peroxide Value, (Meq $\mathrm{O}_{2} / \mathrm{kg}$ ) & $2.60 \pm 0.00$ & $3.85 \pm 0.23$ & $1.20 \pm 0.01$ & $2.96 \pm 0.34$ & 10 \\
\hline Ester value, $(\mathrm{mg} / \mathrm{KOH})$ & $191.61 \pm 2.0$ & $185.87 \pm 0.04$ & $155.44 \pm 0.01$ & $249.42 \pm 0.05$ & \\
\hline Calorific value(J/Kg) & -8180.57 & -6505.68 & -6504.14 & -10002.81 & \\
\hline$\%$ Glycerine & 10.47 & 10.20 & 8.50 & 13.63 & \\
\hline$\% \mathrm{FFA}$ & 2.96 & 1.86 & 0.39 & 0.02 & 0.5 \\
\hline \multicolumn{6}{|l|}{ Fuel properties } \\
\hline Yield (\%) & 100 & 95.7 & 88.5 & 98.5 & - \\
\hline Specific gravity & 0.95 & 0.92 & 0.90 & 0.87 & $0.86-0.92$ \\
\hline Density at $40^{\circ} \mathrm{C}\left(\mathrm{g} / \mathrm{cm}^{3}\right)$ & 0.93 & 0.91 & 0.90 & 0.88 & 0.88 \\
\hline $\begin{array}{l}\text { Kinematic viscosity at } 40^{\circ} \mathrm{C} \\
\left(\mathrm{mm}^{2} / \mathrm{s}\right)\end{array}$ & 38.40 & 11.60 & 9.6 & 2.30 & $1.90-6.0$ \\
\hline Cetane number (min) & 35.48 & 45.15 & 49.55 & 46.10 & $\geq 47$ \\
\hline Smoke point, $0^{\circ} \mathrm{C}$ & 194 & 144 & 137 & 132 & 130 \\
\hline Flash point, ${ }^{\circ} \mathrm{C}$ & 149 & 158 & 127 & 152 & 150 \\
\hline Fire point, ${ }^{\circ} \mathrm{C}$ & 185 & 183 & 174 & 171 & 170 \\
\hline Pour point, ${ }^{\circ} \mathrm{C}$ & -3 & -8 & -2 & -15 & -20 \\
\hline Higher heating value $(\mathrm{MJ} / \mathrm{kg})$ & 44.50 & 45.18 & 40.20 & 42.01 & Not specified \\
\hline
\end{tabular}

The result was an indication that the refined oil was of betterquality after refining treatments. The iodine values obtained for WCO (146.64 $\left.\mathrm{I}_{2} / 100 \mathrm{~g}\right)$, RCO (135.51 $\left.\mathrm{I}_{2} / 100 \mathrm{~g}\right)$ and RCME $\left(117.99 \mathrm{I}_{2} / 100 \mathrm{~g}\right)$ shows remarkable improvement respectively. The slight reduction of $3.08 \%$ in iodine value of $\mathrm{WCO}$ was observed after refinement. This result shows that the refined oil possesses better oxidative stability and can be employing for industrial application purposes. Duhan [21] reported a reduction rate of $25.59 \%$ and $27.37 \%$ of iodine value after refining of respectively. Omojola [20] reported the iodine values of some waste cooking oils like sunflower, depot margarine, sunf oil and palm oil as 111.1, 54.9, 116.7 and $81.7(\mathrm{mg} / \mathrm{KOH})$ against the iodine value of $5.89 \pm 0.14$ $(\mathrm{mg} / \mathrm{KOH})$ observed in this work. The iodine value of 117.99 $\pm 0.67 \mathrm{I} 2 / 100 \mathrm{~g}$ observed in this work were comparable with the iodine values determined elsewhere and also falls within the ASTM D6751-09 standards [8]. The results for saponification value show that both WCO and RCO comprises of fatty acids of moderate long chain lengths $\left(\mathrm{C}_{16^{-}}\right.$ $\mathrm{C}_{20}$ ) due to their relatively low saponification values, i.e. both oil have values below ASTM specified standard $(\geq 312)$. Duhan [21] also reported increase in saponification value of 13.43 and $13.46 \mathrm{mg} / \mathrm{KOH}$ for Citrullus. colocynthis and Pongamia pinnata oils after refinement. The saponification ranges of 188.2 - $207 \mathrm{mg} / \mathrm{KOH}$ have been reported by (Mohammed and Bhargavi) [19] indicating the suitability of oil for further application. Overall, the Table 1 highlights the superior quality of the produced refined oils and reflects the oils to be of good quality. 


\subsection{Fuel properties of WCO, RCO, WCME and RCME}

\subsubsection{The recovery percentage.}

Table 1 show the yield of RCO from $\mathrm{WCO}$ were $88.5 \%$, while the WCME and RCME were 95.7 and $98.5 \%$ respectively. Biodiesel yields from waste cooking oil by two methods of microwave heating and convectional heating had produced $92 \%$ yield without oil refinement [7]. Refining the WCO therefore enhanced the yield.

\subsubsection{Specific gravity}

In Table 1 , the specific gravity values for oils $(0.90-0.95)$ and biodiesels $(0.87-0.92)$ are presented. They are vital within the international edible oil trade market with a suitable limit of $(0.86-0.92)$ at room temperature (ASTM D6751-09 Standards). Increase in the specific gravity of 0.95 was ascertained after the bleaching of WCO and this confirmed the removal of unwanted substances such as free fatty acids, and other oxidation products present in the oil. Similar reduction in specific gravity $(0.87)$ was obtained for the refinement of waste cooking oils of Baphia nitida and Gliricidia sepium [22].

\subsubsection{Density and kinematic viscosity}

Fuel density is one of the factors that affect the atomization and combustion. The densities for WCO, WCME, RCO and RCME obtained were $0.93,0.91,090$ and $0.88\left(\mathrm{~g} / \mathrm{cm}^{3}\right)$, respectively. Mohammed and Bhargavi [19] earlier reported the density ranges of $0.91-0.92\left(\mathrm{~g} / \mathrm{cm}^{3}\right)$ and Rahadanti [11] similarly reported $0.91\left(\mathrm{~g} / \mathrm{cm}^{3}\right)$ for waste cooking oils. Omojola [20] reported the densities of some waste cooking oils like sunflower, depot margarine, sunfoil and palm oil as $0.920,0.917,0.920$ and $0.904\left(\mathrm{~g} / \mathrm{cm}^{3}\right)$ against the observed density of $0.93\left(\mathrm{~g} / \mathrm{cm}^{3}\right)$ reported for waste sunflower cooking oil in this study. This suggest that biodiesel from refined oil using the alkali $(\mathrm{NaOH})$ as catalyst would have better fuel performance due to its lower density (ASTM standard is 0.88) [18]. Biodiesel viscosity is extremely dependent on density. The decrease in viscosity of oil was observed after refining process of the RCO (Table 1). Ryan [23] reported that the consistence of vegetable oils is influenced primarily by fatty acid composition and amount of contaminants. Therefore, the removal of impurities from the oil as results of every refinement stage leads to the reduction in viscosity. Kinematic viscosities of WCO, WCME, RCO and RCME were found to be $38.40,11.60,9.60$ and $2.30 \mathrm{~mm}^{2}$ at $40^{\circ} \mathrm{C}$ respectively. Prafulla [6] reported viscosity of $28.8 \mathrm{~mm}^{2}$ at $40^{\circ} \mathrm{C}$ for waste cooking oil and $2.25-3.10 \mathrm{~mm}^{2}$ at $40^{\circ} \mathrm{C}$ for waste cooking methyl ester. The value of $8.88 \mathrm{~mm}^{2}$ at $40^{\circ} \mathrm{C}$ was given by Rahadanti [11] for viscosity characteristic determination. Also, kinematic viscosity had been reported by Maurizio [24] in the ranges of $36.4-42 \mathrm{~mm}^{2}$ at $40^{\circ} \mathrm{C}$. According to ASTM [18] and European [25] specifications for biodiesel, kinematics viscosity property must be in the range of 1.9-6.0 $\mathrm{mm}^{2} / \mathrm{s}$ and $3.50-5.0 \mathrm{~mm}^{2} / \mathrm{s}$ respectively. The kinematic viscosity value of $2.30 \mathrm{~mm}^{2}$ at $40^{\circ} \mathrm{C}$ obtained indicated that it conform to international standards for biodiesel. Also, Omojola [20] reported the viscosities at $40^{\circ} \mathrm{C}$ of some waste cooking oils like sunflower, depot margarine, sunfoil and palm oil as $31.381,40.927,43.521$ and $44.254\left(\mathrm{~mm}^{2} / \mathrm{s}\right)$ against the observed kinematic viscosity of $38.40 \mathrm{~mm}^{2} / \mathrm{s}$ reported for waste sunflower cooking oil in this work. The viscosity value reduction of $94.6 \%$ ) was drastically observed after refining processes.

\subsubsection{Centane number}

Cetane number of fuel indicates the degree of its ignition feature for compression ignition engines (Codex, 1992) [25]. The cetane number of the produced biodiesel was 84.45 ; this result indicates that the biodiesel cetane number was higher than the minimum specified by European standard. The high cetane number of both RCO and RCME 49.55 and 46.10 (min) showed the biodiesel were good for fuel application, since ASTM of $47 \mathrm{~min}$ is standard [18]

\subsubsection{Smoke, flash, fire and pour points}

These are temperatures at which oil are heated such that the mixture of air and vapour above the oil can go up in flames. The smoke point values obtained from the raw sample (WCO) and refined oil (RCO) was $194^{\circ} \mathrm{C}$ and $97^{\circ} \mathrm{C}$ respectively. This result indicated that after refining process, the smoke point of refined oil decreased and fall below the standard of $130^{\circ} \mathrm{C}$, implying the oil may be safe for fuel because it can ignite at cold temperatures. The WCME (biodiesel) had higher smoke point $\left(144^{\circ} \mathrm{C}\right)$, flash point $\left(158^{\circ} \mathrm{C}\right)$ and fire point $\left(185^{\circ} \mathrm{C}\right)$, while the RCME (biodiesel) had smoke point $\left(134^{\circ} \mathrm{C}\right)$, flash point $\left(152^{\circ} \mathrm{C}\right)$ and fire point $\left(171^{\circ} \mathrm{C}\right)$ respective. Omojola [20] reported the pour points (congealing temperature) of some waste cooking oils like sunflower, depot margarine, sunfoil and palm oil as $-8.65,0.3,-.9 .8$ and $10.25\left({ }^{\circ} \mathrm{C}\right)$ against the observed pour point of $-3^{\circ} \mathrm{C}$ reported for waste sunflower cooking oil. The RCME (biodiesel) values fall within the stipulated ASTM limits for biodiesel which means, the oil would not simply turn jelly-like under cold conditions [18].

\subsubsection{The higher heating value}

The heating value standard was not specified. The European standard for biodiesel specifies a minimum value of $35 \mathrm{MJ} / \mathrm{kg}$. This study shows that the biodiesel combustion values obtained was $42 \mathrm{MJ} / \mathrm{kg}$, which was slightly higher than the specified $35 \mathrm{MJ} / \mathrm{kg}$ [26].

\subsection{Profile of fatty acid of biodiesel}

Table 2 provide the fatty acid profiles of the RCO and WCO in relative to their retention time and percentage composition. The comparable differences between the RCO and WCO show increments in composition in n-heptaldehyde acid (9.09\%), octanoic ethyl ester (276.54\%), benzoic acid, butyl ester (69.79\%), hexadecanoic acid 15- methyl esters (267.33\%) and reduction in 9,17-Octadecanoic acid (99.20\%), and 9- octadecenoic acid(35.98\%), respectively (Figure 2). 
The hexadecanoic acid and tetracosanic acid were absent in the waste cooking oil (WCO).

Table 2: Comparison of fatty acid profiles of waste and refined cooking oils

\begin{tabular}{|c|c|c|c|c|c|c|c|c|}
\hline \multicolumn{4}{|c|}{ Waste cooking oil (WCO) } & \multicolumn{4}{|c|}{ Refined cooking oil (RCO) } & \multirow{2}{*}{$\begin{array}{c}\text { Compa } \\
\text { rable } \\
\text { Differe } \\
\text { nce } \\
(\%) \\
\end{array}$} \\
\hline $\begin{array}{l}\text { Retention } \\
\text { Time }\end{array}$ & Composition & Saturation & $\begin{array}{c}\text { Composition } \\
(\%)\end{array}$ & $\begin{array}{l}\text { Retention } \\
\text { Time }\end{array}$ & Composition & Saturation & $\begin{array}{c}\text { Compositio } \\
\mathrm{n}(\%)\end{array}$ & \\
\hline 9.51 & $\begin{array}{c}\text { n-Heptaldehyde } \\
\text { acid }\end{array}$ & $(\mathrm{C} 7: 1)$ & 0.77 & 13.46 & n-Heptaldehyde acid & $(\mathrm{C} 7: 1)$ & 0.84 & +9.09 \\
\hline 21.37 & Octanoic acid & $(\mathrm{C} 10: 2)$ & 4.86 & 14.50 & Octanoic acid & $(\mathrm{C} 10: 2)$ & 18.30 & $\begin{array}{c}+ \\
276.54 \\
\end{array}$ \\
\hline 23.01 & Benzoic acid & (C11:2) & 3.74 & 15.87 & Benzoic acid & $(\mathrm{C} 11: 2)$ & 6.35 & +69.79 \\
\hline 32.85 & $\begin{array}{l}\text { Hexadecanoic } \\
\text { acid }\end{array}$ & $(\mathrm{C} 18: 2)$ & 1.01 & 22.0 & Hexadecanoic acid & $(\mathrm{C} 18: 2)$ & 3.71 & $\begin{array}{c}+ \\
267.33\end{array}$ \\
\hline 33.41 & $\begin{array}{l}\text { 9-Octadecenoic } \\
\text { acid }\end{array}$ & (C19:2) & 6.42 & 25.46 & Hexadecanoic acid & $(\mathrm{C} 17: 2)$ & 54.10 & Nil \\
\hline 36.92 & $\begin{array}{l}\text { Octadecanoic } \\
\text { acid }\end{array}$ & $(\mathrm{C} 20: 2)$ & 0.03 & 25.51 & Tetracosanic acid & $(\mathrm{C} 24: 2)$ & 0.66 & Nil \\
\hline 39.52 & $\begin{array}{c}9,12,15 \\
\text { Octadecatrienoic } \\
\text { acid }\end{array}$ & $(\mathrm{C} 19: 2)$ & 1.02 & 26.52 & $\begin{array}{l}\text { 9,17-Octadecanoic } \\
\text { acid }\end{array}$ & $(\mathrm{C} 18: 0)$ & 0.24 & -99.20 \\
\hline 39.98 & $\begin{array}{l}\text { Octadecanoic } \\
\text { acid }\end{array}$ & (C20:2) & 29.85 & 28.03 & 9- Octadecenoic acid & $(\mathrm{C} 18: 2)$ & 4.11 & -35.98 \\
\hline 40.69 & $\begin{array}{l}\text { Heptadecanoic } \\
\text { acid }\end{array}$ & (C19:2) & 10.02 & 29.71 & $\begin{array}{c}12- \\
\text { Hydroxydodecanoic } \\
\text { acid }\end{array}$ & (C12:3) & 2.01 & Nil \\
\hline 41.08 & $\begin{array}{c}\text { Pentadecanoic } \\
\text { acid }\end{array}$ & (C17:2) & 38.51 & Nil & Nil & Nil & Nil & Nil \\
\hline 42.84 & $\begin{array}{l}\text { 9-Octadecenoic } \\
\text { acid }\end{array}$ & (C21:4) & 0.24 & Nil & Nil & Nil & Nil & Nil \\
\hline
\end{tabular}

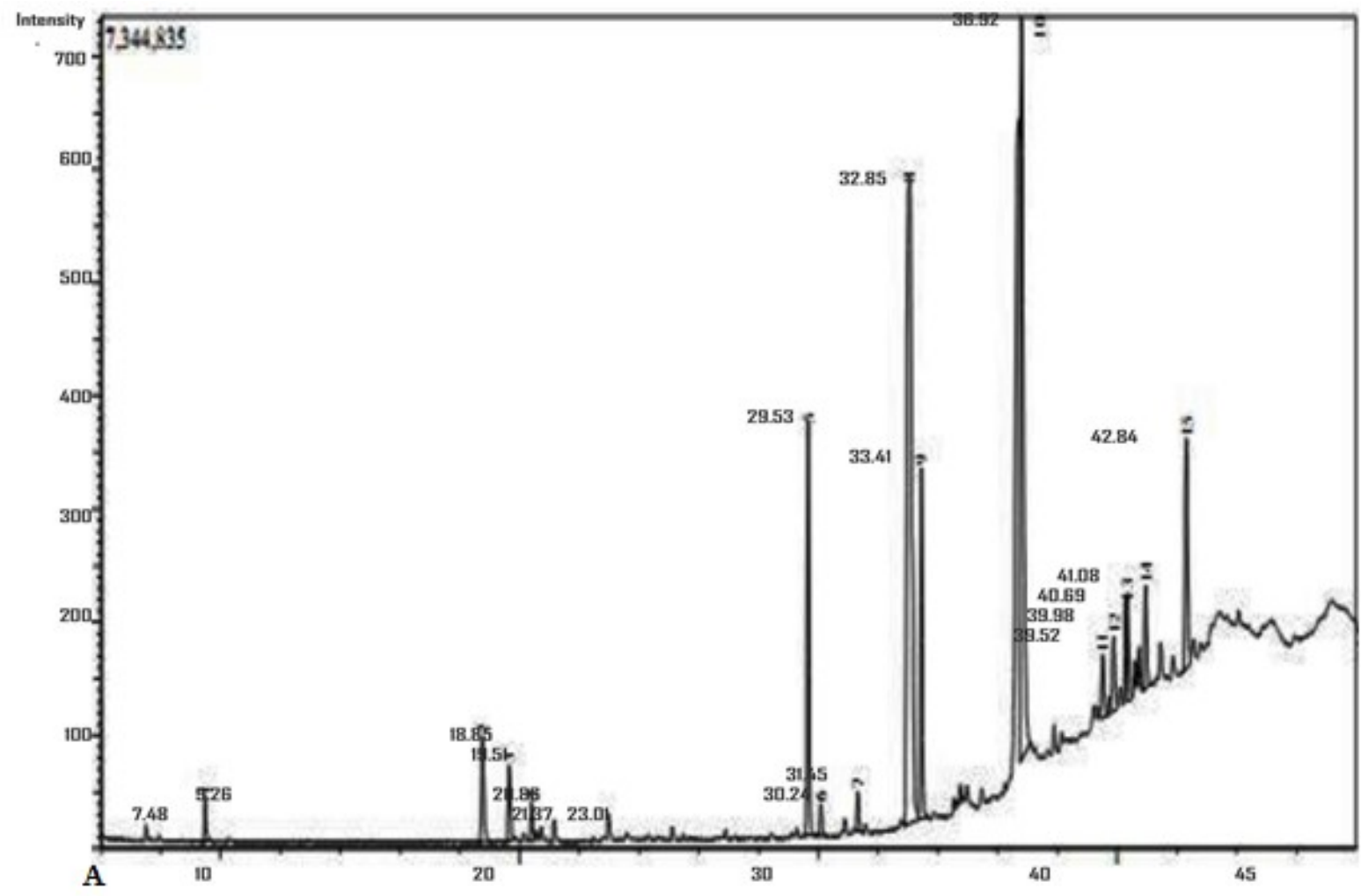




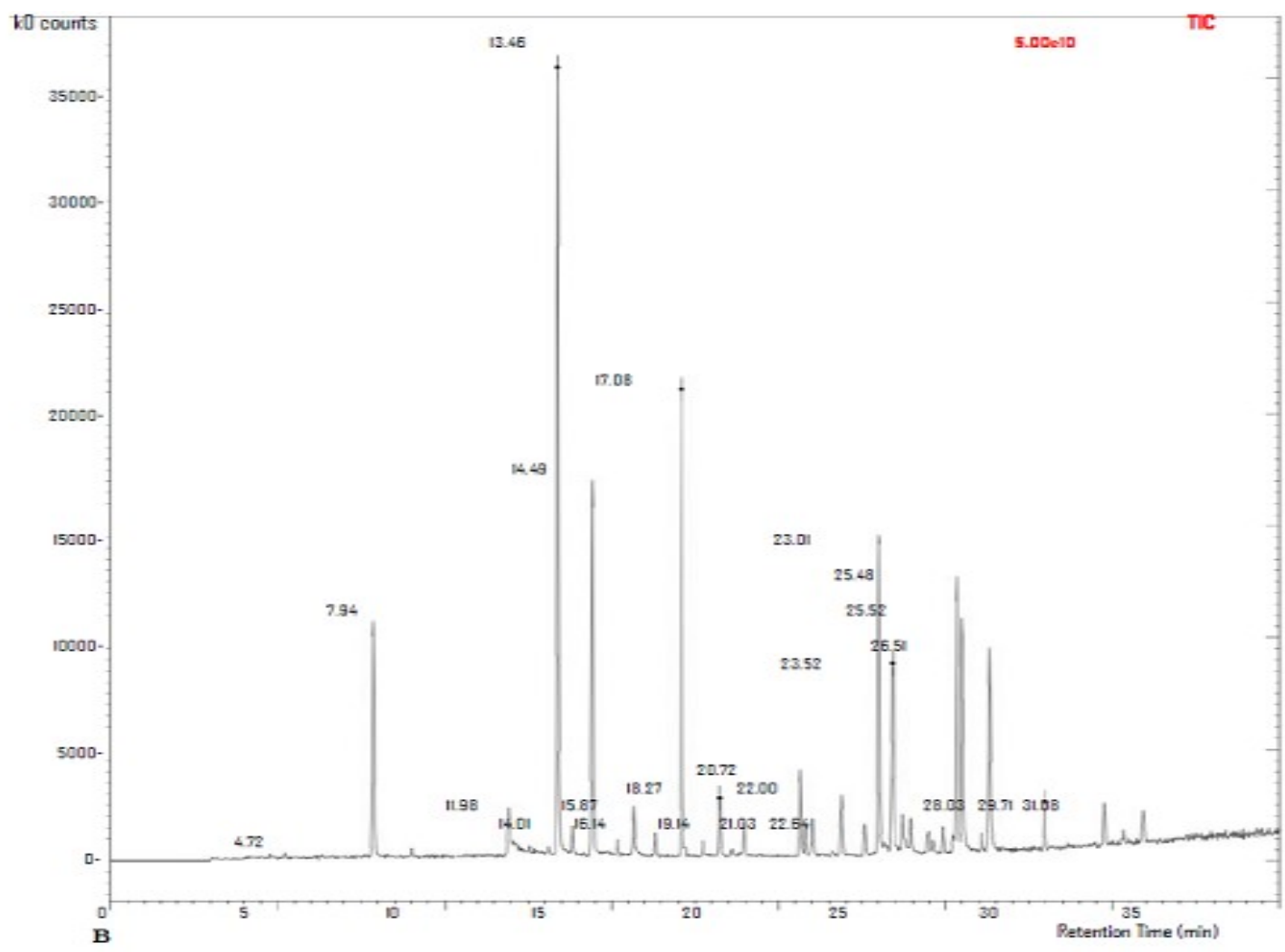

Figure 2: The GCMS chromatograms for both WCO (A) and RCO (B) based biodiesels

But, pentadecanoic acid, 14- methyl-methyl ester (38.51\%) and 9-octadecenoic acid, 12-(acetyloxy)-methyl ester (0.24\%) were present in the waste cooking oil. It was also observed that hexadecanoic acid, methyl ester $(54.10 \%)$ was the most abundant followed by octanoic ethyl ester $(18.30 \%)$, in the refined cooking oil (RCO). The RCO samples have fewer FAs and in smaller quantities which confirms the samples' suitableness as feedstock.
Fourier Transform Infra-red (FTIR) spectroscopy results for both raw and refined biodiesels showed the foremost IR peak regions that indicated chemical changes were found at the finger prints $\left(1600-3600 \mathrm{~cm}^{-1}\right)$. The spectral bands: 1377.22 $\mathrm{cm}^{-1}$ showed the presence of glycerol group $\mathrm{O}-\mathrm{CH}_{2}$ (mono, di and triglycerides). The IR spectral $1747.57 \mathrm{~cm}^{-1}$ corresponds to the presence of ester carbonyl group in the refined oil and biodiesel (Figure 3).

\subsection{The FTIR analysis of biodiesels from WCO and RCO}

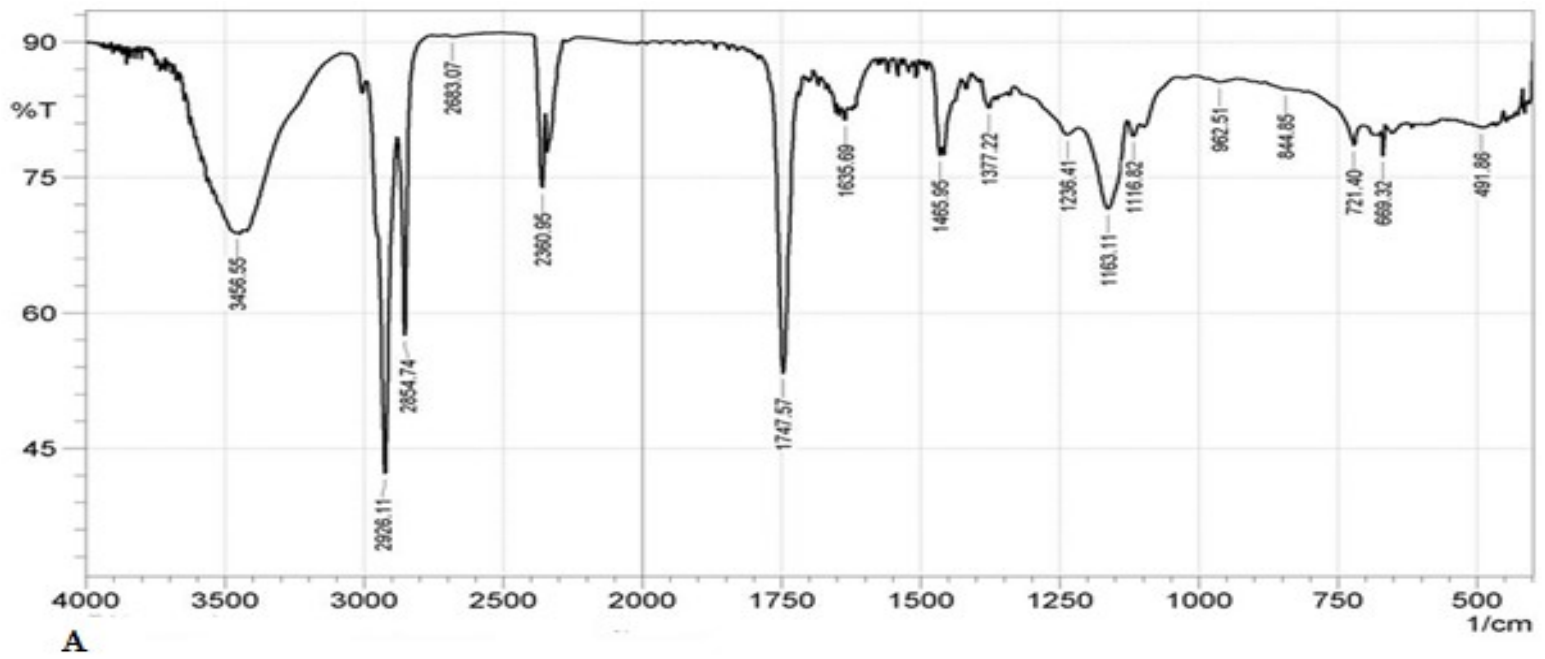




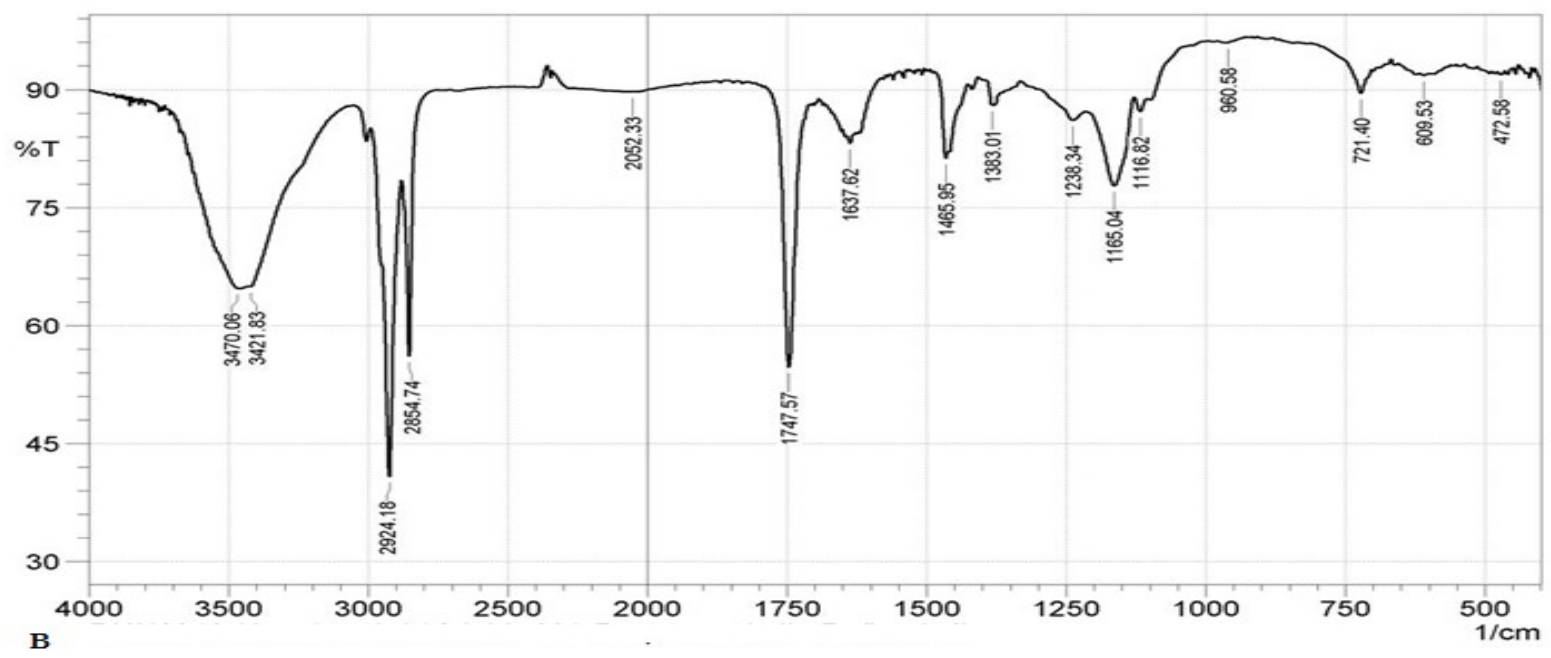

Figure 3: The FTIR spectral for both WCO (A) and RCO (B) based biodiesels

\section{CONCLUSIONS}

This analysis has shown that the properties and FA composition of RCO is also modified by the degree of usage and food things. The application of refined WCO as feedstock for FAME has been found to be economically useful. The utilization of WCO reduces the high value of biodiesel; solves problems associated with the disposal of WCO; eliminates problems associated with contamination of aquatic and terrestrial habitats, and obstruction of drains and pipelines as a result of inappropriate disposal methodologies. The work highlights rising use of waste vegetable oils and fats for biodiesel formulation. Utilization solves contamination of aquatic and terrestrial habitats problems. It showed new refinement methodology in the biodiesel purity against the previous conflicting reports with overall improvement.

\section{REFERENCES}

[1]. Sharma, A, K; Sharma, P.K; Chintala, V; Khatri, N; Alok Patel. "Environment-Friendly Biodiesel/Diesel Blends for Improving the Exhaust Emission and Engine Performance to Reduce the Pollutants Emitted from Transportation Fleets," International Journal of Environmental Research and Public Health, 2020, (17), 3896. doi:10.3390/ijerph17113896

[2]. Mustapha, A.O., Adepoju R.A; Afolabi, Y.T. "Optimization of Vegetable Oil Based Biodiesels by Multi-Response Surface Methodology (MRS) using Desirability Functions". Journal of the Chemical Society of Nigeria, JCSN, 2020, 45 (5); 917 - 924. doi: https://doi.org/10.46602/jcsn.v45i5.517

[3]. Tabatabaei, M; Aghbashlo, M; Dehhaghi, M; Panahi, HKS, "Mollahosseini A., Hosseini M., Soufiyan M.M. Reactor technologies for biodiesel production and processing: A review:", Progress in Energy and Combustion Science, 2019, 74. https://doi.org/10.1016/j.pecs.2019.06.001

[4]. Akubugwo,I.E; Chinyere, V; Ugbogu, A.E. "Comparative Studies on Oil from Some Common Plant Seeds in Nigeria". Pakistan Journal of Nutrition. 2008, 7(4), 570-573.

[5]. Kataria, J; Mohapatra, S.K; Kundu, K "Biodiesel production from waste cooking oil using heterogeneous catalysts and its operational characteristics on variable compression ratio CI engine" Journal of the Energy Institute. 2019, 92, (2): 275-287.

[6]. Prafulla, D.P; Veera, G; Harvind, K.R; Tapaswy, M; Shuguang, G"Biodiesel Production for Waste Cooking Oil Using Sulfuric
Acid and Microwave Irradiation Process" Journal of Environmental Protection. 2012, (3): 107-113.

[7]. Marta, M; Ana, P.S D; Jaime, F; Gomes, P and João, C.B. "Biodiesel Production Processes and Sustainable Raw Materials" Energies 2019, 12, 4408; doi:10.3390/en12234408

[8]. Olaoluwa,R.O; Abolanle,S.A; AJohn, A.O.O; Efere, M.O; Olatunji, S.O; Adedayo, M.S; Muib, A.A; Oyedare, M.A. "Refining, Toxicology Study and Biodiesel Potentials of Used Vegetable Oils", American Journal of Food Science and Technology. 2017, 5, (3): 78-88.

[9]. Abukhadra,M.R; Salam, M.A; Ibrahim, S.M."Insight into the catalytic conversion of palm oil into biodiesel using $\mathrm{Na}^{+} / \mathrm{K}+$ trapped muscovite/phillipsite composite as a novel catalyst: Effect of ultrasonic irradiation and mechanism", Renewable and Sustainable Energy Reviews. 2019, 115.

[10]. Silva,G.F; Camargo,F.L; Ferreira,A.L. "Application of response surface methodology for optimization of biodiesel production by transesterification of soybean oil with ethanol", Fuel Processing Technology. 2011, 92, 407-413.

[11]. Meilana, D.P; Chairul, I; Udiantoro,Y.R; Iryanti, F.N.“'A cleaner process for biodiesel production from waste cooking oil using waste materials as a heterogeneous catalyst and its kinetic study" Journal of Cleaner Production, 2018, 195,1249-1258

[12]. Juan, F.G.M; Carmen,C; Barrios, F.J; Alés-Álvarez; Aida, D.S; Paloma, A.M. "Biodiesel production from waste cooking oil in an oscillatory flow reactor. Performance as a fuel on a TDI diesel engine" Renewable Energy, 2018, 125, 546-556.

[13]. Kulkarni,M.G; Dalai, A.K. "Waste cooking oil- An Economical Source for Biodiesel: A Review", Industrial \& Engineering Chemistry Research, 2006, 45 (9): 2901-2913.

[14]. Tabatabaei, M; Aghbashlo, M; Dehhaghi, M; Panahi, H.K.S; Mollahosseini, A; Hosseini,M; Soufiyan, M.M; Mollahosseini, A; Hosseini; Soufiyan,M.M; "Reactor technologies for biodiesel production and processing: A review", Progress in Energy and Combustion Science, 2019,74.

[15]. Zheng, S; Kates, M; Dube, M.A. "Acid-catalyzed production of biodiesel from waste frying oil", Biomass \& Bioenergy, 2009, 30, 267.

[16]. Bencheikh, K; Atabani,A.E; Shobana, S; Mohammed,M.N; Uğuz,G; Arpa, O; Kumar,G; Ayanoğlu, A; Bokhari, A. "Fuels properties, characterizations and engine and emission performance analyses of ternary waste cooking oil biodiesel-diesel-propanol blends" Sustainable Energy Technologies and Assessments, 2019, 35.

[17]. Canakci, M and Gerpen, V. "Biodiesel Production from Oils and Fats with High Free Fatty Acids," Journal of American Society of Agricultural and Engineers, 2001, 44, (6): 1429-1436. 
[18]. American Society for Testing Materials (ASTM). ASTM Standards Methods: ASTM pub; Philadelphia. (2003)

[19]. Abdul Raqeeb, M and Bhargavi, R. "Biodiesel production from waste cooking oil. Journal of Chemical and Pharmaceutical Research, 2015, 7(12):670-681.

[20]. Omojola, A; Emmanuel,I.O; Freddie, L.I. "Comparative study of properties and fatty acid composition of some neat vegetable oils and waste cooking oils" International Journal of Low-Carbon Technologies, 2019, 14, 417-425.

[21]. Duhan, A; Duhan, S; Kumari, B. "Effect of Chemical Refining on Citrullus Colocynthis and Pongamia Pinnata Seed Oil" African Journal of Food, Agriculture, Nutrition and Development, 2012, 12: 3 .

[22]. Adewuyi, A; Oderinde, R.A; Ajayi, I.A."The metal composition, proximate properties and the effect of refining on the physico- chemical characterization of Baphia nitida and Gliricidia sepium seed and seed oil" Journal of Food Technology, 2009, 7(2):43-49.

[23]. Ryan, T.W; Dodge,L.G; Callahan, T.J."The effects of vegetable oil properties on injection and combustion in two different diesel engines" Journal American Oil Chemical Society, 1984, 61, 16101619.

[24]. Maurizio, C; Sonia, C; Silvia, C. "A Pilot-Scale Study of Waste Vegetable Oil Transesterification with Alkaline and Acidic Catalysts" Energy Procedia. 2014, 45, 198 - 206.

[25]. CODEX Alimentarius Commisions. Recommended International Statndards For Edible Arachis Oil'. Food and Agricultural Organization of the United Nation. World Health Organizaton, Geneva, Switzerland. 1992, 1; 6-19.

[26]. EN14214. Automotive fuels-fatty acid methyl esters (FAME) for diesel engines requirements and test methods, Berling, Germany: Beuth-Verlag, 2003. https://doi.org/10.3403/30176475 